\title{
THE PRACTICAL APPLICATION OF PHILOSOPHY AS INTERPRETED BY P. SLOTERDIJK
}

\author{
Hanna Ivchenko \\ Applicant at the Department of Philosophy, Sociology and Management of Social \\ and Cultural Activities, South Ukrainian National Pedagogical University \\ named after K. D. Ushynsky, Ukraine \\ e-mail: annshymko@gmail.com,orcid.org/0000-0002-6525-1869
}

\section{Summary}

The article considers the anthropological aspects of the philosophical heritage of the famous German philosopher P. Sloterdijk. On the basis of learning of the work of the philosopher "You must change your life", there were highlighted and analyzed the key concepts, with the help of which it is realized the deployment of the theoretical construct "care of the self." These are such concepts as "teacher", "mentor", "tutor", "school", "identity", "vertical stress", "Philosophy ", "habit." It develops the idea that the philosophy of P. Sloterdijk appears in its practical incarnation in the techniques anthropotechniques. Previous attempts to change the world have failed, says Sloterdijk. Moreover, if practices do not work, theory must look for other solutions. Sloterdijk turns to ancient philosophical thought, to Buddhism, to the techniques of meditation and asceticism, to the masters of modern literature, to reflections on contemporary sports culture.

These considerations of P. Sloterdijk acquire special value and relevance in view of the fact that the modern Ukrainian education system, continues to cultivate the training of highly specialized specialists, subjects of production, not their own life activities.

Keywords: care of the self, antropotechniques, human being, anthropological practice, exercise culture, identity.

\section{DOI: https://doi.org/10.23856/4704}

\section{Introduction}

The problem of a person, his/her place in the world, is multiaspectual and complex. Modern society, which is actively creating an era of "altered reality", is interested in clarifying the possibilities of a person in this new reality. In this regard a whole range of global anthropological challenges arise, which require immediate and definite answers related to the understanding of the new ontology and new epistemology of a person of 21st century, because the curve of "living life", the dynamics of modern homo sapiens, the choice of future development programs will largely depend on them.

The question posed to E. Fromm "But why is modern human so anxious and confused?" (Fromm, 2006: 12) gets a new sounding in the context of processes of globalization and formation of electronic, network culture that contribute to the "reduction" of the "mass of the mind" and the growth of the "mind of the mass'. Improving the means of mastering the surrounding world, a human, according to Erich Fromm, lost the main goal, i.e. human: "While becoming the master of nature, he has become the slave of the machine which his own hands built. With all his knowledge about matter, he is ignorant with regard to the most important and fundamental questions of human existence: what man is, how he ought to live, and how the tremendous energies within man can be released and used productively" (Fromm, 2006: 12). 
It is no coincidence that in the 20th century one began to speak more and more often about such phenomenon as "anthropological disaster": this is "an event occurring to man himself and connected with civilization, the meaning of which is that something vital for him may irreversibly break down in man" (Golik, 2002: 213).

According to the famous Russian philosopher F.I. Girenok, as a result of an anthropological disaster, "a void, which is filled with social institutions" is formed in a person, professional qualities are valued in him, and "the personality ... does not find demand and dies", "a person loses subjectivity" (Girenok, 2002: 398). In the world of growing anthropological stress, there is less and less sincerity, truth, faith, feelings, emotions. The emptied man cannot find himself and grasps only the "here and now" (Girenok, 2002: 399), but encounters an even greater emptiness.

P. Sloterdijk is a worthy continuer of the philosophical and literary tradition of F. Nietzsche, a poetic philosopher of Germany, a brilliant essayist, a master of words and intellectual provocations.

Such important works of the philosopher as "Critique of Cynical Reason" and the trilogy "Spheres" have been translated into Ukrainian by now.

A national researcher and translator of Sloterdijk's work, M. Kultayeva ("You Must Change Your Life" (2009) believes that this text presents a kind of "anthropotechnical turn" of modern Western philosophical thought. Sloterdijk addresses the basics of human existence, writes about how people try to change their lives in different ways to remain Human in any situation.

According to Sloterdijk, a person is the only "animal" who does not know how to move forward except by setting impossible tasks for himself. The author "defines an exercise as any operation by means of which the qualification of the actor to perform the same operation is preserved or improved, whether it is declared an exercise or not" (Kultayeva, 2014: 14). According to Sloterdijk, a man becomes a generator of all kinds of exercises through which he tries to discover himself.

In the German philosopher's thoughts, it is possible to distinguish some key concepts with the help of which the most important construct of anthropological practices, "care of the self", is deployed. For the reasons stated above, a reference to this theoretical construct seems to be a very urgent task. The aim of this publication is to explicate the philosophical construct "care of the self", fixing the way it is deployed in P. Sloterdijk's essay "You Must Change Your Life".

\section{The concept of "teacher"}

Sloterdijk tries to present human development in the form of "life in exercise", life learning from mentors (tutors, leaders). Interestingly, the word "teacher" is complemented by a number of related cultural terms with slightly different semantic emphases: mentor, trainer, and tutor.

Under the supervision of trainers who correct the mistakes of their wards, cultural achievements are formed like sports records that athletes achieve. This is a peculiar "anthropotechnology" that assumes strict observance of the corresponding rules, prescriptions, execution of which is obligatory.

The features of the actions of a mentor or a tutor are associated with the need to transform the human psychics and are determined by the fundamental feature of a person, i.e. laziness.

The mentor, trainer and educator in their work not only note laziness as a fundamental feature of a person, but also emphasize another integral feature of human existence, namely, the ability to perform exercises. A series of exercises for human and social wellness is formed based on habits, which act in this case in a positive quality, as stabilizers of new knowledge. As M. Kultaeva 
notes, such habits undergo a kind of selection procedure, "a selection contest for the best exercise program", which is fixed in the course of psychogenesis and sociogenesis of humankind (Smirnov, 2004: 64). Thus, the trainer or tutor triggers the mechanism of antropotechniques. Sloterdijk even calls the latter a kind of a peculiar anthropological constant: in any epoch "forms of exercises demonstrate always the same figure: in order to learn to be active, one must first turn into a passive one" (Smirnov, 2004: 64). The function of a tutor is rather to turn a person into $a$ student, to teach him to learn. The teacher is metaphorically represented as a trainer who manages "by means of simple discipline to form in his wards the ability to recognize and choose their life path among a huge number of other possible proposals" (Kultayeva, 2014: 85).

A real teacher does not destroy the student's independent search, but clarifies it by helping another to go his own unique path. Very often, the relationship between a student and a teacher develops into friendship.

Thinking on teaching, Sloterdijk models the culture in the perspective of the younger ones, who preserve and improve the heritage they inherited from the previous generation.

\section{The concept of "school"}

The institute of school is central to Sloterdijk's anthropological research. The school, from the philosopher's point of view, is a latent world force that continues to dominate humanity and guide it, unfortunately not always in the right directions.

The conceptualization of the school as a living space comes from the sophists, who "wanted to make a person a being capable of resisting the greatest threat to human existence, viz. amechania. Translated from Greek, it is helplessness because man no longer has mechane, namely, cunning, tricks, auxiliaries. Amechania is a state in which the human being should never be. All education is the overcoming of amechania" (Kultayeva, 2014: 41). Sloterdijk extracts a new meaning of this word for the modern consciousness, referring to ancient Greek language: "skillful", "tool, device". Now "amechania" already carries negative connotations it means the absence of the ability to contrive and do the impossible - to outsmart nature in its own ways, to make the forces of inertia serve to overcome inertia. The institution of school and the idea of the school itself are central to Sloterdijk's thoughts. The philosopher subsumes all educational institutions under the rubric "school", which is considered not on an empirical, but on a metatheoretic level (Smirnov, 2004: 66).

The slogan "learning is not for school, but for life" includes the entire pedagogical experience of humankind. Its approbation took place over many centuries and still remains a reference point for the activities of schools as educational institutions and as a specific "basic training camp" (Sloterdijk's expression). By this expression, the philosopher means a kind of living space. Continuous learning throughout life implies an expansion of such a camp.

In Sloterdijk's thinking on school, there is an original idea about the development within school education of an inner verticality that sooner or later forms the "system of degrees" with which the formation of a "class" society begins.

\section{The concepts of "identity" and "vertical stress"}

Sloterdijk understands identity in a very peculiar way. Thus, from his point of view, people who manifest a particular identity perceive themselves as ready-made, identity is like a plastic package for storing laziness, identities are displayed in the "identity park" (Kultayeva, 2014: 78). 
The expressions "to become yourself" or "to find yourself", according to Sloterdijk, imply not so much the knowledge and identification of something "given" to the individual, embedded in him, as the requirement for self-realization in the process of moving along the path of life. However, sooner or later, a person notices that all that he considers his essential ego not only distinguishes him from others, but also unites him with them. One gets one's body from one's parents, one's life experiences depend on external influences, one's social status and possessions matter only insofar as others recognize them, and the products of spiritual creativity, when objectified, become completely independent of him. Therefore, Sloterdijk does not see any prospects for developing the study of identity in the humanities. An established identity, according to the philosopher, suspends the development of man and culture.

Sloterdijk finds a more successful research alternative to identity in the concept of "vertical stress". The philosopher understands this term as the ability of an individual to outgrow himself and the comfortable "base camp". It is a stress that comes from the middle of human. It creates the self of the artisan, which can be achieved by performing exercises. Therefore, "an internal stress" is inextricably connected with another key concept of Sloterdijk, i.e. "exercise culture". Every person has a chance to change his life if he performs exercises. In general, this is done through writing, logic, gymnastics, music and art (Kultayeva, 2014: 80).

I would like to draw attention to the fact that Sloterdijk's idea of "vertical stress" is very similar to the "ladder" of spiritual and moral perfection, the movement from lower value worlds to higher ones, from the temporary and relative to the eternal and absolute.

Friedrich Nietzsche and Michel Foucault are the main authors on whom Sloterdijk relies in developing the theme of "vertical stress". Nietzsche ("Thus Spoke Zarathustra") metaphorically defines a person as a rope that is "stretched between an animal and an over human", Foucault emphasizes the connection between exercises, discipline and the development of human resources.

Previous attempts to change the world have failed, says Sloterdijk. Moreover, if practices do not work, theory must look for other solutions. Sloterdijk turns to ancient philosophical thought, to Buddhism, to the techniques of meditation and asceticism, to the masters of modern literature (for example, F. Kafka and R. Rilke), to reflections on contemporary sports culture.

With all the variety of its content and forms, the question "Who am I?" comes to three: "What I can?", "What do I dare?" and "What am I able to do?" (in the Kantian version: "What can I know?", "What shall I do?", "What can I hope for?") ... Can is an effective-existential category, it describes a range of objective possibilities and choices that determine the potential frameworks of human activity. Dare is a moral-volitional category that describes the level of sights and moral potential. To be able is a cognitive and practical category, which includes knowledge and skills, with the help of which it realizes the possibilities inherent in the life situation and in the human's own nature (Smirnov, 2004: 83).

\section{The concept of "philosophy as athletics"}

It is hardly possible to actualize the theme of care of the self without turning to philosophy. In Plato's texts (above all in the dialogue Alcibiades the First) this theme was quite clearly identified and problematized.

Sloterdijk observes that the word "philosophy" itself contains an overtone to two crucial athletic qualities, which were widely endorsed in Plato's time. Firstly, stating of the aristocratic position of "philotimia", the love of time, that is, of the victorious authority that the winners had in the competitions; secondly, of "philoponia", which means the love of ponos, that is, of efforts, exertion. 
However, philosophy is not only a love of "victorious authorities" and "efforts". According to Sloterdijk, philosophy is only worth something if it activates not only its athletic, but also acrobatic components. Acrobatics is no longer an easy exercise, but an opportunity to make an impression through the impossible. Acrobatic existence "detrivializes" life, putting repetitions at the service of the non-repeatable. Or, as M. K. Mamardashvili said, there is a shift of consciousness in philosophy.

In philosophical acrobatics, all steps are first, but each of them may turn out to be the last. The following ethical position becomes key for an athlete: to bypass all circumstances through submission of the improbable (Kultayeva, 2014: 83).

Philosophy as a paideia has declared itself from the very beginning as a school of universal synthesis. On the one hand, it gave an answer to the question of how to understand the diverse and unfamiliar world in its integrity, how to keep people safe in situations of incessant risks, and on the other hand, it offered a certain set of educational practices, the so-called "new training of man" to make him capable of living in the city and the state.

\section{The concept of "habits"}

In the analysis of educational practices, Sloterdijk turns to thinking about habits and laziness formed during these habits, considering them as static formal characteristics of a human. He believes that they are a necessary part of human existence, because at one time they contributed (and do contribute) stabilization and rooting of new knowledge and opportunities for their application. However, in today's low-predictable world, the formation of habits as organizational forms of teaching already reveals negative aspects. Habits contribute more to the implementation of the teacher's attitudes, rather than to the self-realization of the subjects of learning. "Habit" as a word and as a deed means the actual obsession of the psychics with a block of acquired perceptions, a more or less irreversible embodiment of properties. As long as this block remains unchangeable, it is impossible to begin new learning", the German philosopher is convinced (Kultayeva, 2014: 76). It turns out that acquiring new knowledge not with the help of habits and established rules, but in spite of them is an effective and necessary condition for the modern educational process. The researcher advises to protect the emptiness as a special value, because it is impossible to fill the filled spirit again. Then there is a very difficult question of how does a mentor save this emptiness? Sloterdijk writes: "To change one's life now means to shape oneself through inner activation as a subject of exercise who must transcend one's addictions and habitual life as well as one's life among one's own perceptions" (Kultayeva, 2014: 82).

These considerations of $\mathrm{P}$. Sloterdijk acquire special value and relevance in view of the fact that the modern education system, despite declaring the development of personal abilities as a goal, continues to cultivate the training of highly specialized specialists, subjects of production, not their own life activities. Modern educational institutions have become a place of real non-meeting. Their activities are strictly regulated and assumed by a number of programs and decrees. The relationship between teachers and pupils/students and parents is very often formal. The world of teachers and the world of students overlap very little.

Knowledge has value only when it is in demand by a person, otherwise it is dead and alienated.

Perhaps, when forming habits, it is advisable to turn to ideas about practices.

Sloterdijk is right to contest the identification of a practice exclusively with labor. Like any other practice, labor practice is divided into semantic and pragmatic. Mentoring in these 
different spheres of labor practices is as different as they are. Labor, which guarantees the survival of the human species and improves their mode of existence, is led by masters who control and program technological processes.

By reducing all culture to "exertions", Sloterdijk responds to its present state, characterized by the decadence of theorizing, the absence of ideas that pave the way to the future, the concern only for short-term profit, the dominance of evaluative opinions.

The absolute imperative "You must change your life" is a kind of challenge, i.e. rethinking based on a thorough and comprehensive analysis of educational experience, practices of paideia.

The only option to change your life is change through activity. Those who want to change oneself must work on themselves. The author prefers to use the word "exercise".

\section{Conclusions}

As noted above, the purpose of this publication was to reveal the way in which the construct of "care of the self" is deployed in P. Sloterdijk's essay "You Must Change Your Life". By revealing the meanings that the philosopher attaches to the terms "teacher", "mentor", "tutor", "school", "identity", "philosophy", "habit", it is possible to find comprehensive meaning of the educational practices that one carries out throughout his life, revealing their interior potential.

Sloterdijk's essay presents a variant of the practical application of philosophy, with detailed recommendations for each individual. Sloterdijk places the negative image of man at the heart of his anthropological study, defining him as a "lazy being". However, the main attention is paid not to the description of human laziness, but to methods of overcoming them.

Without radical changes in human consciousness and psychics, any reforms of social life brought from outside are destined for failure. The mentor, trainer and tutor in their work rely on an integral feature of human existence - the ability to perform exercises. The trainer or mentor triggers the anthropotechnical mechanism. The teacher is metaphorically represented as a trainer who manages to turn a person into a student, teach him to learn. A person needs $\boldsymbol{a}$ teacher. Teachers and educational institutions allow the process of self-improvement and selfactualization to be triggered.

Sloterdijk is an opponent of the thesis about the supposedly unchangeable nature of human. Identification contributes to the affirmation of the individual, but a one-sided understanding of it may lead to standardization and impoverishment, primitivization. A person needs not so much variants of self-identification, but rather an educator who teaches to abandon conventions and changes the consciousness and, in fact, the identity of the pupil.

The researcher gives a very valuable advice: to protect the emptiness as a special value, because it is impossible to fill the filled spirit again.

\section{References}

1. Fromm, E. (2006). Chelovek dlya sebya [Man from himself]. Minsk: Harvest. [in Russian]. 2. Bragin, A. V. (2010). Problema massy razuma i ustojchivost' razvitiya [The problem of the mass of reason and the sustainability of development]. Vestnik Ivanovskogo gosudarstvennogo universiteta. Seriya «Gumanitarnye nauki», 2, 59-67. [in Russian].

3. Golik, N. V. (2002). Antropologicheskaya katastrofa: real'nost' ili illyuziya? [The anthropological disaster: reality or illusion?], Social'nyj krizis i social'naya katastrofa. Sbornik materialov konferencii [Social crisis and social disaster. Collection of conference materials]. St. Petersburg [in Russian]. 
4. Girenok, F. I. (2002). Antropologicheskaya katastrofa [Anthropological disaster], Uchenie Cerkvi o cheloveke: materialy Bogoslovskoj konferencii russkoj Pravoslavnoj Cerkvi [The Teaching of the Church about man: materials of the Theological Conference of the Russian Orthodox Church]. Moscow [in Russian].

5. Sloterdijk, P. (2014). Ty musysh zminyty svoie zhyttia [You must change your life]. Filosofiia osvity, 1 (14), 76-90. [in Ukrainian].

6. Kultayeva, M. (2014). Antropolohichnyi povorot ta yoho sotsialno-filosofski ta filosofsko-osvitni implikatsii u teoretychnykh rozvidkakh P. Sloterdaika [Anthropological turn and its socio-philosophical and philosophical-educational implications in the theoretical explorations of P. Sloterdijk]. Philosophy of Education, 1 (14), 54-75. [in Ukrainian].

7. Smirnov, I. P. (2004). Sociosofiya revolyucii [Sociosophy of the Revolution]. St. Petersburg: Aleteya. [in Russian].

8. Michel, D. (1999). Mishel' Fuko v strategiyah sub"ektivacii: ot «Istorii bezumiya» do "Zaboty o sebe» [Michel Foucault in the strategies of subjectification: from "History of Madness" to "Care of the Self"]. In Materialy lekcionnyh kursov 1996 - 1998 godov [Materials of lecture courses of 1996 - 1998]. Saratov: Izd-vo Povolzhskogo filiala Ros. ucheb. centra [in Russian]. 9. Kon, I. S. (1987). V poiskah sebya: Lichnost' i ee samosoznanie [In Search of Myself: Personality and its self-consciousness]. Moscow: Politizdat. [in Russian]. 